\title{
Brukeren vet best hvor skoen trykker
}

\author{
Når sykdom rammer, må fysisk og psykisk helse ses i sammenheng. Pasienter må ha verktøy til å håndtere \\ den mentale støyen som sykdom kan gi. Ved Diakonhjemmet Sykehus har Brukerutvalget bidratt til at \\ kliniske helsepsykologiske tjenester er blitt en del av tilbudet.
}

Sko som trykker gjør ikke bare vondt i foten. Går man lenge nok, får man gjerne vondt i resten av kroppen også. Vedvarende sykdom er en sko som trykker, spesielt for den som har den på, men også for dem som skal hjelpe. Helsevesenet må ha kunnskap om både sko og føtter, men må også kunne kommunisere godt med den som har skoen på, altså brukerne. Her har sykehusenes brukerutvalg en viktig rolle ved å bidra til samarbeid og kommunikasjon.

Brukerutvalget ved Diakonhjemmet Sykehus i Oslo arbeider på systemnivå og gir råd og innspill til sykehusledelsen i arbeidet med å utforme tilbudene til pasienter og pårørende. Brukerutvalget er representert i sykehusstyret, kvalitets- og pasientsikkerhetsutvalget, klinisk etisk komité og møter i andre lederfora. Ett av de prosjektene det har engasjert seg $\mathrm{i}$ handler nettopp om at sko ikke bare gjør vondt i foten.

\section{Fysisk og psykisk}

Som brukere har vi lenge visst at kropp og sjel påvirker hverandre. Det er jo tross alt brukeren som skal mestre sykdom med ressurser som i stor grad er knyttet til person; hvem du er som menneske, hvordan du tenker, hva du har i bagasjen og hva du har rundt deg av støtte. Når sykdom sitter i kroppen, får vi god medisinsk behandling i det somatiske helsevesenet, men innenfor det medisinske fagfeltet opplever vi at hele mennesker fortsatt er mindre synlige enn organer og ledd. Mange vegrer seg for å fortelle om psykiske plager fordi de er redde for at legen da vil tenke at «dette er jo bare psykisk». Det kan komplisere både diagnostisering og behandling dersom man for eksempel har en hjertesykdom og unngår å fortelle om angstplager som også kan gi hjertebank og pustebesvær.

Sykdom, både akutt og kronisk, gir risiko for å utvikle angst og depresjon. Studier ved somatiske sykehus tyder på at $15-20 \%$ av pasienter med hjerteinfarkt har en depresjon etter diagnostiske kriterier (1). Tilsvarende tall finnes for en rekke andre somatiske sykdommer. Depresjon er en nesten like stor risikofaktor for død som røyking (2).

Både røyking og depresjon kan forebygges, men vi er definitivt mer opptatt av røyking enn av depresjon. Å forebygge psykiske lidelser ved somatisk sykdom innebærer først og fremst å anerkjenne at somatisk sykdom gir økt risiko. Dernest må vi gi pasient, pårørende og helsepersonell relevant informasjon om kjennetegn og tiltak.
Sist, men ikke minst, må vi gi pasienten selvhjelpsverktøy slik at han eller hun selv kan forebygge at sykdommen blir tyngre å bære enn nødvendig.

\section{Psykologiske verktøy}

Klinisk helsepsykologi er et fagfelt der psykologisk kunnskap og psykologens kliniske ferdigheter anvendes i tverrfaglig behandlingstilbud, rehabilitering, palliasjon og helsefremming for pasienter med somatisk sykdom eller funksjonshemning (3). Vi trenger verktøy for å håndtere den mentale

\section{«Hele mennesker er fortsatt mindre synlige enn organer og ledd»}

støyen som sykdom kan gi, og verktøy for å følge opp behandling og råd fra helsevesenet. Det er ikke nødvendigvis slik at man gjør det som er bra for helsen selv om man har kunnskapen. Er man redd, bekymret, nedstemt eller har svekket selvfølelse og evne til egenomsorg, er det sjelden man gir seg selv kloke råd. En kognitiv terapeutisk tilnærming for å bygge opp styrke til å tåle sykdom, endre usunne vaner og holde seg frisk og yrkesaktiv så lenge som mulig, er et godt hjelpemiddel for mange.

Brukerutvalget har vært opptatt av å synliggjøre nytten brukeren kan ha av klinisk helsepsykologiske tjenester i somatiske sykehus. Vi har utfordret sykehusledelsen i samarbeidsmøter, hatt med fokus på psykisk helse i utformingen av pasientforløp og brukt anonymiserte pasienthistorier for å formidle betydningen av psykiske helsetjenester i somatikken.

Brukerutvalget har også vært aktiv deltaker i sykehusets strategiarbeid for 2014-18, der det nå fremkommer at Diakonhjemmet Sykehus skal møte pasientens behov med en helhetlig tilnærming og innovativ styrke (4).

Gjennom etablering av Enhet for psykiske helsetjenester $i$ somatikken har de kliniske helsepsykologiske tjenestene blitt et fast tilbud til brukere og deres pårørende ved Diakonhjemmet Sykehus. Helsepsykologiske tiltak kan settes inn ved f.eks. smerte, utmattelse, søvnvansker, angst og bekymring, depresjon, gjennomføring av medisinske prosedyrer, sprøytefobi, mestring av kronisk eller akutt sykdom eller når pårørende og familie trenger hjelp. Vi vil nå arbeide videre for at brukerutvalg $i$ andre helseforetak også utfordrer sykehusledelsen og etterspør en helhetlig tilnærming til pasienten. I ethvert pasientforløp i somatikken ønsker vi at psykisk og fysisk helsehjelp skal være likeverdige.

\section{Hilde Sofie Hamre \\ Elin Fjerstad \\ elin.fjerstad@gmail.com}

Hilde Sofie Hamre (f. 1956) er utdannet fysioterapeut, spesialist i hjerte- og lungefysioterapi og er leder av Brukerutvalget ved Diakonhjemmet Sykehus.

Forfatter har fylt ut ICMJE-skjemaet og oppgir ingen interessekonflikter.

Elin Fjerstad (f. 1964) er psykologspesialist ved Enhet for psykiske helsetjenester i somatikken, Diakonhjemmet Sykehus.

Forfatter har fylt ut ICMJE-skjemaet og oppgir ingen interessekonflikter.

\section{Litteratur \\ 1. Lichtman JH, Bigger JT Jr, Blumenthal JA et al. Depression and coronary heart disease: recom- mendations for screening, referral, and treatment: a science advisory from the American Heart Asso- ciation Prevention Committee of the Council on Cardiovascular Nursing, Council on Clinical Car- diology, Council on Epidemiology and Prevention, and Interdisciplinary Council on Quality of Care and Outcomes Research: endorsed by the Ameri- can Psychiatric Association. Circulation 2008; 118 : $1768-75$ \\ 2. Nasjonalt folkehelseinstitutt. Psykiske lidelser i Norge: Et folkehelseperspektiv. Rapport 2009: 8 . www.fhi.no/eway/default.aspx?pid=239\&trg= Content 6510\&Main 6157 $=6263: 0: 25,6336 \&$ MainContent_6263=6510:0:25,6349\&Content $6510=6259: 80180: 25,6349: 0: 6250: 18: \cdots: 0: 0$ (7.10.2014). \\ 3. Berge T, Lang N. Manifest for klinisk helsepsyko- logi. Tidsskr Nor Psykolforen 2011; 48: 323-31. \\ 4. Diakonhjemmet. Strategiplan 2014-2018. http://diakonhjemmetsykehus.no/cms/site/0/ forside/om-sykehuset/Hvem+er+vi/_attachment/ 2774 ? ts $=144307 \mathrm{bcff} 2(3.10 .2014)$.}

Mottatt 1.10. 2014, første revisjon innsendt 6.10. 2014, godkjent 7.10. 2014. Redaktør: Hanne Støre valeur.

Publisert først på nett. 